major-university communication positions as there are conventional science-journalism jobs. Heuss himself has just made the switch to become head of communications at the Swiss Tropical and Public Health Institute in Basel.

The change is rooted in the growing demand for online content and a need for institutions to keep the public informed about taxpayer-funded research. Some publicly funded US universities are under hiring freezes, but many other institutions around the world are beefing up their communications teams.

Science writers working in academia need many of the same skills as science journalists, including a solid writing ability, research experience and digital know-how. Communications jobs have shifted from putting out the university's news of the day to targeting select audiences directly with marketing messages. Rather than solely writing press releases, science writers at universities now also craft speeches to donors and multimedia web presentations meant to highlight undergraduate research. Audiences include patients, students, faculty members, alumni, donors, legislators and decision-makers, as well as the regional, state and global public.

Borchelt says that research institutions are experimenting with how best to woo online audiences. "We can't take our traditional news products, like press releases, and just transfer them over to a new medium. [New media] work a lot differently from how old media worked," he says.

Writers must not only be comfortable with digital platforms and social media, but also be able to manage them wisely, says Melissa Lutz Blouin, director of news and publications for the University of Florida Academic Health Center in Gainesville. "Is [the news] conducive to a video or a slide show? A feature in a magazine that gets sent to decisionmakers? Or is it short enough to do a tweet?" she asks. "If you can do all of that at some level, you're going to be more employable."

Recruiters stress the importance of being a collaborative 'people person', because a science writer will probably be part of a marketing team. "It's not yet a saturated market for people who can do both science and writing and do both well," says Borchelt.

\section{GOING GLOBAL}

Conventional science journalism is not in decline everywhere: in the developing world, it is thriving (see 'An international snapshot of science writers'). Newly independent media in countries such as India, Venezuela and some African nations have growing, highly educated audiences that demand science coverage. Editors need journalists who can cover stories about the effects of environmental crises and how technology booms are aiding regional economies. Jean-Marc

Fleury, executive director of the World Federation of Science Journalists, who is based in Gatineau, Canada, notes that in the past few years, newspapers in Cameroon, Nigeria and Uganda have brought in science desks or pages. Internet access is still patchy in many of these areas, so print publications retain their appeal.

"In the past decade, Egypt has our first independent newspaper and now the region has a lot of publications that have a section or a weekly column

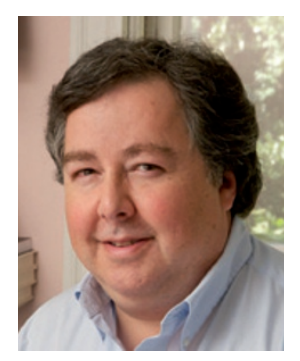
talking about science," says Bothina Osama, the Cairobased Middle East and North Africa news editor for SciDev.net, a nonprofit organization based in London that provides science news focused “There are staff opportunities that didn't exist before." Dan Fagin on the developing world. "That's given a nice boost in science-journalism jobs."

Osama and about 20 colleagues founded the Arab Science Journalists Association in 2002. The organization now has more than 230 members. "Since the Arab Spring, people are becoming more interested in reading about science because they see it as a force of socioeconomic advancement in the region. There is a political will to have more science news," says Osama.

In 2006, the World Federation of Science Journalists launched its Science Journalism Cooperation Project (SjCOOP), which seeks to raise the profile and standards of science journalism in Africa and the Arab world, and is funded by government internationaldevelopment agencies from the United Kingdom, Canada and the Netherlands. The programme matches general journalists from this region with science-journalism mentors from Europe and North America. Editors-inchief in the Middle East and Africa are asking for good journalists who can cover science, says Fleury.

But as elsewhere, Fleury says, would-be science journalists in the developing world should be open to jobs not clearly labelled 'science correspondent'. Irion suggests that young science writers must be go-getters in the job market. "I'm optimistic for any student who is willing to be entrepreneurial and wants to explore writing about science across different platforms," he says. "Yes, parts of the science-writing ecosystem have withered on the vine. But opportunities keep popping up."

Kendall Powell is a science writer based in Lafayette, Colorado.

\section{UNITED STATES}

\section{Geospatial shortage}

US agencies face a shortfall in employees who can visually depict and assess global security threats, finds a report released on 25 January by the National Academies in Washington DC. The Future U.S. Workforce for Geospatial Intelligence cites a need to measure Earth for surveying and environmental monitoring; determine objects' geometry through photos; and use visual data to synthesize information. It predicts personnel shortages at the US National Geospatial-Intelligence Agency owing to retirements, changing defence priorities and the need for international humanitarian support. Keith Clarke, a geographer at the University of California, Santa Barbara, and chairman of the report committee, suggests that interested scientists develop their skills in spatial thinking, mathematics and statistics.

\section{EUROPEAN UNION}

\section{Inclusive rankings}

The European Union on 30 January launched U-Multirank, a university ranking system based on broad criteria. In addition to research, used in most existing systems, it assesses universities' quality of teaching and learning; international networking; external partnerships; and regional engagement. Some 500 universities are expected to participate. A consortium led by the Centre for Higher Education in Gütersloh, Germany, and the Centre for Higher Education Policy Studies in Enschede, the Netherlands, will compile the first round of rankings by February 2014. The system is meant to improve transparency and reduce elitism in rankings, says a European Council representative.

\section{ENDOWMENTS}

\section{University assets fall}

Values of and returns from US university endowments have fallen, says a survey, but faculty recruitment is unlikely to be affected. The National Association of College and University Business Officers (NACUBO) in Washington DC and the Commonfund, an investmentmanagement firm in Wilton, Connecticut, studied 831 institutions and found that endowments fell by an average of $0.3 \%$ between 2011 and 2012. Ken Redd, NACUBO director of research and policy analysis, says that faculty hiring is usually supported by other accounts and probably will not tighten as a result of the drop. 